\title{
PRIMOGENITURE AND ILLEGITIMACY IN AFRICAN CUSTOMARY LAW: THE BATTLE FOR SURVIVAL OF CULTURE
}

\author{
Jelili A. Omotola*
}

\begin{abstract}
Nowadays, African cultures seem threatened by the effects of rapid socio-economic transformation processes and by the invasion of foreign models and mass cultural products. The ways of life, the ancestral values, the endogenous forms of solidarity and expression, the traditional knowledge and know-how are marginalized or lost. The rich diversity of local cultures, oral traditions, and languages as well as the African cultural and natural heritage are also seriously endangered.
\end{abstract}

\section{INTRODUCTION}

African culture has been battling for its survival from the days of colonialism. $^{2}$ In recent times, especially with the introduction of new constitutions in Africa, the culture of African people has faced new challenges. This Article discusses the threat of extinction faced by African culture. It seeks to put the culture in true perspective, using primogeniture and illegitimacy as examples. The aim is to show its relevance, and to counsel caution in its handling by Governments and other institutions. For practical reasons, the courts' approach to African culture will be the centerpiece of the Article, since its continued existence depends largely on the attitude of judges towards it. The Article will disclose differing judicial attitudes in the interpretation of constitutional provisions. The African Charter on Human and Peoples' Rights

* LL.B., LL.M., Ph.D. (London) Senior Advocate of Nigeria, Honorary Research Associate, University of the Witwatersrand. The idea of this article occurred to me after my Staff Seminar at the University of Capetown in May 2002. I am grateful to my Colleagues at the University of the Witwatersrand, School of Law, for their useful comments on earlier drafts of this article: Ian Currie, Lawrence Monnye, and Likhapa Mbatha of the Centre for Applied Legal Studies (CALS). Thanks also go to my other colleagues in the School of Law for their contributions during the Staff Seminar at which this article was first presented.

1. See The United Nations Educational, Scientific and Cultural Organization, MediumTerm Strategy (2002-2007) for the Africa Region, July 1-4, 2002, Dakar, Senegal, para. 48, pt. V Culture [hereinafter Medium-Term Strategy].

2. See M. Pieterse, It's a 'Black Thing': Upholding Culture and Customary Law in a Society Founded on Non-racialism, 17 S. AFR. J. HUM. RTs. 364, 368 (2001). The author observes that " [c]olonial powers regarded the indigenous populations of conquered territories as uncivilised [sic] 'savages' and viewed indigenous law as a set of primitive rules, which was irrational, inseparably linked with religion ...." Id. 
is brought into focus. It will be stressed that when interpreting the Charter, all of its provisions must be taken together so as to give full effect to it. The article is divided into two sections. Section A discusses the primogeniture rule, while the discussion of illegitimacy follows in Section B. The Article concludes by making recommendations, which hopefully, will ensure the survival of African culture.

\section{THE PRIMOGENITURE RULE}

Primogeniture has been in existence in Africa since the early times. It permits only male issues to inherit the property of a person who dies intestate. The rule has been criticized on the ground that it prohibits female children from inheriting. ${ }^{3}$

The discussion will start with the celebrated case of Mthembu v. Letsela ${ }^{4}$ decided in South Africa. Here, the intestate had been in an apparent customary relationship with the Appellant. The deceased, his parents, the Appellant and her two daughters lived together on a ninety-nine year lease property registered in his name. His only child, Tembi, was one of the Appellant's daughters. The first Respondent, the father of an intestate, claimed title to the house and instituted proceedings for eviction against the Appellant and her daughter. The Magistrate, who had earlier made an order for the deceased's estate to devolve according to customary law, was the second Respondent.

The Appellant alleged that there was a customary marriage between her and the deceased. In support of this allegation, she attached to her affidavit a copy of an acknowledgment of receipt of the first installment of $R 900$ towards her lobola of 2000.00. The balance was to be paid soon thereafter. The deceased, however, died before it could be paid. The Appellant challenged the validity of the customary law rule preventing Tembi from inheriting due to her gender. She also claimed that she and her daughter could not be evicted from the property.

The matter first came before Justice Le Roux in the High Court. The learned judge was unable to resolve the factual dispute relating to the existence of a customary marriage between the parties. He referred that issue for oral evidence and adjourned the matter indefinitely. With regard to the constitutionality of the customary law rule of primogeniture, he said:

3. See V. Bronstein, Reconceptualizing the Customary Law Debate in South Africa, 14 S. AfR. J. HUM. RTS. 388 (1998); K. L. Robinson, The Minority and Subordinate Status of African Women Under Customary Law, 11 S. AFR. J. HUM. RTs. 457 (1995). See generally T. W. BENNETT, HUMAN RIGHTS AND AFRICAN CUSTOMARY LAW UNDER THE SOUTH AFRICAN Constitution 86 (1995); W. V. Meide, Gender Equality v. Right to Culture: Debunking the Perceived Conflicts Preventing the Reform of the Marital Property Regime of the 'Official Version' of Customary Law, 116 S. AFR. L.J. 100 (1999).

4. 2000 (3) SA 867 (CC). 
If one accepts the duty to provide sustenance, maintenance and shelter as a necessary corollary of the system of primogeniture (a feature which has been called 'one of the most hallowed principles of customary law'), I find it difficult to equate this form of differentiation between men and women with the concept of 'unfair discrimination' as used in Section 8 of the Constitution .... I I cannot accept the submission that the succession rule is necessarily in conflict with Section 8 . It follows that even if this rule is prima facie discriminatory on grounds of sex or gender and the presumption contained in Section $8(4)$ comes into operation this presumption has been refuted by the concomitant duty of support. ${ }^{5}$

When the matter later came before Judge Mynhardt at the second High Court trial, the learned judge remarked:

The applicable African customary law of succession in the present case is to the effect that Tembi cannot be regarded as the deceased's heir and that the first respondent is his heir. This is so because of the principle, or system, of primogeniture, which is applied in African customary law .... If I were to accede to $\mathrm{Mr}[$.] Trengove's request and declare the customary law rule of succession invalid because it offends against public policy, I would, I believe, be applying Western norms to a rule of customary law, which is still adhered to and applied by many African people. ${ }^{6}$

He held that there was no marriage between the parties. Thus, it was unnecessary to discuss the constitutionality of the rule, because Tembi was illegitimate and would not be eligible to inherit even if she were a male. This decision will be analyzed further under Section B, when the discussion turns to illegitimacy.

On appeal to the Supreme Court of Appeal, Judge Mpati, delivering the judgment of the Court, said:

The customary law of succession in Southern Africa is based on the principle of male primogeniture. In monogamous families the eldest son of the family head is his heir, failing him the eldest son's eldest male descendant. Where the eldest son has predeceased the family head without leaving male issue the second son becomes heir; if he be [sic] dead leaving no male issue the third son succeeds and so on through the 
sons of the family head. Where the family head dies leaving no male issue his father succeeds. It follows that in terms of this system of succession, whether or not Tembi is the deceased's legitimate child, being female, she does not qualify as heir to the deceased's estate. Women generally do not inherit in customary law. When the head of the family dies his heir takes his position as head of the family and becomes owner of all the deceased's property, movable and immovable; he becomes liable for the debts of the deceased and assumes the deceased's position as guardian of the women and minor sons in the family. He is obliged to support and maintain them, if necessary from his own resources, and not to expel them from his home. ${ }^{7}$

The Court held, however, that the Constitution could not apply since it did not have retroactive effect.

In the recent case of Nonkululeko Bhe v. Khayelisha, ${ }^{8}$ the third Applicant and the deceased lived together as husband and wife for a period of twelve years. Two minor children were born of the relationship. They are the first and second Applicants in the case. The deceased acquired an immovable property during his lifetime and lived there with the three Applicants until the time of his death. After his death the three Applicants continued to live on the property. The second Respondent claimed that he was the intestate's heir by virtue of African customary law and, therefore, entitled to inherit his property. He also indicated that he intended to sell the property to defray the funeral expenses incurred as a result of the deceased's death. Judge Ngwenya noted that the attitude of the courts towards African customary law has been a cause for concern. He referred to the case of Du Plessis v. De Klerk ${ }^{9}$ in which Judge Mokgoro said that "customary law [has been] lamentably marginalised, and allowed to degenerate into a vitrified set of norms alienated from its roots in the community." In spite of these remarks, Judge Ngwenya proceeded to declare:

We should make it clear in this judgment that a situation whereby a male person will be preferred to a female person for purposes of inheritance can no longer withstand constitutional scrutiny. That constitutes discrimination before the law. To put it plainly, African females, irrespective of age or social status, are entitled to inherit from their parents' intestate like any male person. This does not mean that there may not be

7. Mthembu, (3) SA at 876.

8. No. 9489/2002 (C.H.C. Sept. 25, 2003) (unreported judgment of the Cape High Court delivered by Ngwenya, J. (on file with author).

9. 1996 (3) SA 850 (CC).

10. Id. 
instances where differentiation on gender line may not be justified for purposes of certain rituals. As long as this does not amount to disinherison or prejudice to any female descendant. On the facts before us, therefore, the first two applicants are decided to be the sole heirs to the deceased's estate and they are entitled to inherit equally. ${ }^{11}$

This decision amounts to overturning the customary law rule of primogeniture without any regard to its implications.

The case of Mthembu $v$. Letsela was referred to by counsel for the Respondents but was not discussed because the Constitution was not applicable to it. There were, of course, important issues relating to the primogeniture rule which were discussed by the courts in Mthembu, which were not considered by the learned judge in this case. Two considerations might have influenced his decision. First, the Respondent planned to sell the house to meet funeral expenses. Although this is outrageous, it is not a sufficient reason for declaring invalid the custom of the people, which is seen as the keystone of their culture. The best the court could have done was to make an order preventing the sale of the property and thereby "not throw out the baby with the bath water."12 Second, Counsel for the Applicants was smart enough to bring sentiment to becloud the decision of the learned judge by making it appear as if the primogeniture rule was introduced by the Black Administration Act and against the Blacks. Counsel argued and the Judge agreed that "the only reason why the first two applicants are not entitled to inherit from their father's estate $a b$ interstatio in these proceedings is threefold. Firstly, they are black, secondly they are females, and thirdly they are illegitimate."

In truth, the Act does not introduce the rule, but recognizes it as part of African culture. This point was stressed in Mthembu by Judge Mpati when dealing with the regulations promulgated under the Act. The learned judge said:

What needs to be stressed from the outset is that the regulation in issue did not introduce something foreign to Black persons, as was the case in Machika en Andere v. Staatspresident en Andere. It merely gave legislative recognition to a principle or system which had been in existence and followed, at least, for decades. ${ }^{14}$

11. Nonkululeko Bhe, No. $9489 / 2002$.

12. See Masango v. Masango S 66-86 (unreported judgment of the Supreme Court of Zimbabwe) (on file with author); see also Matambo v. Matambo, 1969 (3) SA 717 (RA).

13. See Nonkululeko Bhe, No. $9489 / 2002$.

14. Mthembu, 2000 (3) SA at 880; see also Machika en Andere v. Staatspresident en Andere, 1989 (4) SA 19 (T). 
If Judge Ngwenya had examined the rule more carefully, and had considered the views expressed on it by other judges, he probably would have followed the path of caution. The primogeniture rule in customary law is similar to the common law rule under which all the realty (immovable properties) vested in the intestate passed to his heir, the eldest male child, subject to the rights of the surviving spouse. Some chattels (movable properties) known as heirloom also descended to the heir. At common law the heir takes beneficially, but in customary law he takes on behalf of the family. The court did not tamper with the common law rule, but required Parliament to intervene in 1925 when it deemed fit to do so after full investigation and consultation. ${ }^{15}$

In Mthembu v. Letsela, Judge Mynardt declined an invitation by counsel to develop the Customary Law rule. He said:

In the present case I therefore decline the invitation to develop the customary law of succession which excludes women from participating in intestacy and which also excludes children who are not the eldest male child. In any event, because the development of that rule, . . . would affect not only the customary law of succession but also the customary family law rules, I think that such development should rather be undertaken by Parliament and in this regard I can do no better than to repeat, in regard to customary law, what was said by [Judge] Kentridge ... in . . . the Du Plessis case, ... in regard to the common law, namely[:] 'The radical amelioration of the common law has hitherto been a function of Parliament; there is no reason to believe that Parliament will not continue to exercise that function. ${ }^{16}$

Judge Mpati with the Supreme Court of Appeal, also declined to develop the rule, preferring to leave it to the South African Law Commission, who are in a better position to make proper recommendations to Parliament. The learned judge said:

[Counsel] contended that the rule is based on 'inequality, arbitrariness, intolerance and inequity', all of which are repugnant to the new constitutional order. He urged us to develop the rule ... so as to allow all descendants, whether male or female, legitimate or illegitimate, to participate in intestacy ... we would be ill-equipped to develop the rule for lack of relevant information. Any development of the rule

15. See R. E. Megarry \& H. W. R. Wade, The Law of Real Property 539-48 (5th ed. 1984).

16. Mthembu, 1998 (2) SA at $686-87$. 
would be better left to the legislature after a process of full investigation and consultation, such as is currently being undertaken by the Law Commission. ${ }^{17}$

In the case of Magaya v. Magaya, ${ }^{18}$ discussed later, Judge Muchechetere insisted that the function of reform of the rule is that of the legislature, and not the court. In this regard he observed:

Matters of reform should be left to the legislature .... In the case of succession a court could not simply rule customary norms void; it would have to stipulate how much widows could inherit and in what circumstances. Details of this nature cannot be determined in judicial proceedings. The proper medium for reform would be legislation, which permits full investigation of the social context and consultation with interested groups. ${ }^{19}$

Section 6 of the South African Promotion of Equality and Prevention of Unfair Discrimination $\mathrm{Act}^{20}$ provides that "neither the State nor any person may unfairly discriminate against any person." Section 8 of the Act also provides that, "subject to Section 6, no person may unfairly discriminate against any person on the ground of gender, including the system of preventing women from inheriting family property."21 These new statutory provisions came into effect after Mthembu.

The question, therefore, is whether these provisions will have the effect of invalidating the primogeniture rule. To answer that question, one must ask whether the new provisions are covered by the 1996 Constitution. In comparing the Constitution and the Act, the only difference is the specific reference in the Act to discrimination, which prevents women from inheriting family property. Therefore, the question is whether those provisions of the Act add anything to what the Constitution already covers in Section 9. Subsection 4 of Section 9 provides that "no person may unfairly discriminate directly or indirectly against anyone on one or more grounds in terms of subsection (3)."22 The grounds listed in the latter subsection are "race, gender, sex, pregnancy, marital status, ethnic or social origin, color, sexual orientation, age, disability, religion, conscience, belief, culture, language and birth." ${ }^{, 23}$ Discrimination on ground of sex is included in this provision. Therefore, the Act did not add

17. Mthembu, 2000 (3) SA at 881,883 .

18. 1999 (1) ZLR 100 (S).

19. Id. at 114 .

20. South African Promotion of Equality and Prevention of Unfair Discrimination Act 4 of 2000 (S. Afr.).

21. Id. $\$ 8$, para. (c).

22. Id. $\S 6$.

23. S. Afr. Const. $\$ 9(4)$. 
materially to the existing provisions in Section 9 of the Constitution. Under the Constitution and the new Act, discrimination must be shown to be fair. Section $9(5)^{24}$ of the 1996 Constitution, like Section $8(4)^{25}$ of the 1993 Constitution, put the burden of proof of the fairness of the discrimination on the person who wants to take advantage of the discrimination. The 1993 Constitution requires prima facie proof of discrimination, which is presumed to be sufficient proof thereof. Under the 1996 Constitution, discrimination is unfair unless it is established that the discrimination is fair. Both the Constitution and the Act are concerned with unfair discrimination and not discrimination per se.

In the Nigerian case of Mojekwu v. Mojekwu, ${ }^{26}$ a well-known case in that country, the Appellant claimed that the deceased, the owner of the property, was his father's only brother who predeceased his father. The deceased had two wives, the Respondent, Caroline, and another wife, Janet. Caroline had a son who died in 1970, and had no issue. Janet had two daughters. The deceased bought the property in dispute from the Mgbelekeke family of Onisha under Kola tenancy. ${ }^{27}$ The Appellant claimed that he inherited the property under the native law and custom of Nnewi, which is their home, because he was the eldest surviving son of his father and the eldest male in the Mojekwu family. He paid the necessary kola, as consideration to the Mgbelekeke family, who recognized him as a kola tenant. Respondent denied Appellant's claim. Under the Mgbelekeke family customary law of Onitsha, both male and female children can inherit the property of an intestate. The customary law of Nnewi is known as Oli-ekpe, ${ }^{28}$ and under it only males can inherit. The trial judge decided that the applicable law is the lex situs, that is, the law where the land is situated. In this case, the customary law was therefore that of the Mgbelekeke family of Onitsha, and not the Oli-ekpe.

The Nigerian Court of Appeal agreed with the trial judge that the applicable law is the lex situs, which is the Mgbelekeke family customary law. Justice Niki Tobi, delivering the judgment of the court, expressed the following view on the Oli-ekpe custom:

24. Id. $\S 9(5)$. This section provides that "[d]iscrimination on one or more ground listed in subsection (3) is unfair unless it is established that the discrimination is fair." Id.

25. Id. $\S 8(4)$. This section provides that "prima facie proof of discrimination on any of the grounds specified in subsection (2) shall be presumed to be sufficient proof of unfair discrimination as contemplated in that subsection, until the contrary is established." Id.

26. 1997 (7) N.W.L.R. 283 (Nig.).

27. Id. at 301 . Section 2 of the Kola Tenancy Law of 1935 (of then Eastern Region of Nigeria) defines a Kola tenancy as a right of use and occupation of any land, which is enjoyed by any native in virtue of a Kola or other token payment made by such native or any predecessor in title or in virtue of a grant for which no payment in money or in kind was enacted. The significant legal incident of a Kola tenancy is that the tenant has a limited right of disposal. The Kola tenant enjoys all the rights of an absolute owner but not the right of absolute disposition. Id.

28. Oli-ekpe is sometimes referred to as lli-kpe. 
The appellant claims to be that "Oli-ekpe". Is such a custom consistent with equity and fairplay in an egalitarian society such as ours where the civilized sociology does not discriminate against women? Day after day, month after month and year after year, we hear of and read about customs, which discriminate against the womenfolk in this country. They are regarded as inferior to the menfolk. Why should it be so? All human beings, male and female are born into a free world and are expected to participate freely, without any inhibition on grounds of sex; and that is constitutional. Any form of societal discrimination on grounds of sex, apart from being unconstitutional is antithesis to a society built on the tenets of democracy, which we have freely chosen as a people. We need not travel all the way to Beijing to know that some of our customs, including the Nnewi Oli ekpe custom relied upon by the appellant are not consistent with our civilized world in which we all live today, including the appellant. In my humble view, it is the monopoly of God to determine the sex of a baby and not the parents. Although the scientific world disagrees with this divine truth, I believe that God, the Creator of Human being, is also the final authority of who should be male and female. Accordingly, for a custom or customary law to discriminate against a particular sex is to say the least an affront on the Almighty God himself. Let nobody do such a thing. On my part, I have no difficulty in holding that the Oliekpe custom of Nnewi is repugnant to natural justice, equity and good conscience. ${ }^{29}$

Oli-ekpe custom should not be seen as contrary to natural justice, equity, and good conscience. Female children are not prevented from benefiting. The family property that the heir inherits is to be used for the benefit of all family members who will fall under his care. It does not belong to him in his personal capacity. What is inequitable in asking property to be held for others or in saying males should hold for females, so long as no one that is entitled is thereby deprived?

This is the principle upon which the English Trust was founded in order to keep the property safe and ensure evenhandedness in its administration. Under English law, property could be held in trust by one person known as trustee, on behalf of others who are called beneficiaries. Sometimes, the trustee also has beneficial interest in the property, and will, in the circumstance, have dual capacity. ${ }^{30}$ The learned justice referred to the custom as unconstitutional

29. Mojekwu, 1997 (7) N.W.L.R. at 304-05.

30. See G. W. Keeton \& L. A. Sheridan, The Law of Trusts 2-6 (12th ed. 1993) (discussing the definition of trusts); see also Jacobs, Law of Trusts in Australia in R. P. 
and antithetical to a society based on the tenets of democracy. He said, "any form of societal discrimination on grounds of sex, apart from being unconstitutional is antithesis to a society built on the tenets of democracy, which we have freely chosen as a people." ${ }^{31}$ Since his judgment was delivered in 1997, the only Constitution that could apply in Nigeria was the Federal Republic of Nigeria Constitution of 1979. Most of its provisions were suspended, abrogated, or modified by the Military in 1984, by its Decree No. 1 of 1984. Although fundamental rights relating to discrimination, contained in Section 39, Chapter IV of the Constitution, were preserved, it is doubtful whether this provision would justify the dismissal of the primogeniture rule, especially considering the provisions of Section 20 of the same Constitution, which provide for the protection of Nigerian culture.

In Magaya v. Magaya ${ }^{32}$ another celebrated case decided by the Supreme Court of Zimbabwe, the deceased had two wives by customary law marriage. Appellant, a female, was the only child by the first wife, and the Respondent was one of the three sons by the second wife. Appellant was the eldest child of the deceased. Respondent's brother was the eldest of the three sons and eligible to succeed the deceased, but declined to take up heirship. He said that he would be unable to look after the family. The Community Court appointed Appellant as the heiress to the estate, without notifying the Respondent and other interested parties. The court later cancelled the appointment of Appellant upon application by Respondent challenging the appointment. The presiding magistrate awarded the heirship to Respondent because the customary law rule of intestate succession favored males over females. The court relied on section 68 (1) of the Zimbabwe Administration of Estates Act, ${ }^{33}$ which provided that if an African married according to customary law or custom dies intestate, his estate must be administered and distributed according to the customs and usages of the tribe or people to which he belonged.

On appeal to the Supreme Court of Zimbabwe, the Court held that, although the rule constitutes a prima facie discrimination against females, and therefore could be a prima facie breach of the Constitution of Zimbabwe, which by section 23(1) and (2) forbid discrimination on grounds of race, tribe, place of origin, political opinion, color or creed, the exemption in Section 23(3) excludes application of this provision in matters relating to succession and the application of African customary law. Based on these grounds, the court dismissed the appeal. Judge Muchechetere, delivered the lead judgment and rationalized the rule thus:

In my understanding of African society, especially that of a patrilineal nature, the perpetual discrimination against women stems from the fact that women were always regarded as

Meagher \& W. M. C. Gumow, Jacobs' Law Of Trusts In Australia 1-6 (4th ed. 1977).

31. Mojekwu, 1997 (7) N.W.L.R. at 304.

32. 1999 (1) ZLR 100 (S).

33. Zimbabwe Administrations of Estates Act, ch. 68(1) (Nig.). 
persons who would eventually leave their original family on marriage, after the payment of roora/lobola, to join the family of their husbands. It was reasoned that in their new situation-a member of the husband's family-they could not be heads of their original families, as they were more likely to subordinate the interests of the original family to those of the new family. It was therefore reasoned that in their new situation they would not be able to look after the original family. It was also reasoned that the appointment of female heirs would be tantamount to diverting the property of the original family to that of the new family. This would most likely occur on the death of a female heir. Then her property would be inherited by her children who would be members of her new family. This in my view would be a distortion of the principles underlying customary law of succession and inheritance. $^{34}$

Muchcchetere stressed the obligations of the heir towards the family, as did Le Roux, and Mpati, in Mthembu. He also acknowledged the responsibility of the heir under customary law to maintain and support the family of the deceased and referred to two cases in support: Masango v. Masango ${ }^{35}$ and Matambo v. Matambo ${ }^{36}$. Indeed, in Masango, the judge refused to grant an order to evict the heir's late father's wife and children because the heir did not provide alternative accommodation for them. Assuming, therefore, that the duty of support is central to the primogeniture rule, how may it be enforced? Is it enough to refuse eviction as in Masango or can the court do more, so as to disentitle an heir who abandons his responsibilities to the family?

In Matombo v. Matombo, the court approved a departure where the most senior male was bypassed, and the bulk of the property of the deceased was given to a junior male, on the ground that if all the property was given to the most senior for the rest of the family, he might not deal with it to the best advantage of all other members of the family. ${ }^{37}$

The ground upon which the rule was saved in $M$ thembu, namely the concomitant duty of support, must be enforced by the courts in such a way that it does not impose empty obligations on the heirs. Members of the family of the deceased must have locus standi to compel the successor to fulfill his customary law duties. Failure to fulfill this duty should be made a civil wrong. In its discussion paper on customary law, the South African Law Commission

34. Magaya, 1999 (1) ZLR at 109; cf. AJ Kerr, The Bill of Rights in the New Constitution and Customary Law, 114 S. AFR. L.J. 346 (1997).

35. S-66-86 (unreported judgment of the Supreme Court of Zimbabwe) (on file with author).

36. 1969 (3) SA $717,717 \mathrm{G}$ (RA).

37. Cf. Magaya, 1999 (1) ZLR at 109 (where the eldest son declined voluntarily on the ground that he would not be able to fulfill obligations attaching to the inheritance). 
expressed concern about the efficacy of this concomitant duty of support. ${ }^{38}$ It said:

Admittedly, the heir has a duty to maintain the deceased's dependant out of the estate, and, on the strength of this duty, it has been held that customary law formally complies with the Bill of Rights. Even so, the law is no longer effective to achieve its major purpose, which is to provide a material basis of support for the deceased's surviving spouse and immediate descendants. The time has therefore come to amend customary rules that discriminate on grounds of gender, age, or birth and to give the deceased's immediate family more secure rights. ${ }^{39}$

While one may agree with the concern expressed by the Commission, this will not justify its call for the abrogation of the rule. The task lies not in the abrogation, but rather in ensuring compliance with the rule. The approach of the Court in Masango and Matambo, which seeks to ensure compliance, ought to be followed. Only those who can comply with the duty of support should be allowed to assume hiership. The primogeniture rule is inherently of great value, and as admitted elsewhere in the Commission's Paper, the rule has long been assumed to be the "keystone of customary law" 40 because it seeks to strengthen the family rather than the individual. For that reason, it should be preserved.

In Ryland v. Edros, ${ }^{41}$ it was held that the courts must take into account the plural nature of South African society when interpreting the Constitution, and the duty was placed on the judiciary to apply the values of equality and tolerance of diversity. This was also echoed in another South African case, Amod v. Multilateral Motor Vehicle Accidents Fund, ${ }^{42}$ where Judge Mohamed held that to deny the appellant compensation on the ground that the only duty of support, which the law will protect, is that flowing from a marriage solemnized and recognized by one faith or philosophy, to the exclusion of others, is an untenable basis for the determination of the boni mores of society. The following two cases will show the attitude of courts in other societies to the issue of culture.

The first is the Canadian case of Attorney-General v. Lavell. ${ }^{43}$ The case involved two appeals, which were taken together. In the first appeal, Respondent, L, was an Indian woman who married a Non-Indian. As a result,

38. South African Law Commission, Discussion Paper 93, Project 90 (2000).

39. Id. at para. 4.1. (Background to the Investigation).

40. Id. at para. 4.2 .6 (Intestate succession).

41. 1997 (2) SA 690 (CC).

42. 1999 (4) SA 1319 (CC).

43. [1974] S.C.R. 1349. 
her name was removed from the Indian Register pursuant to Section 12(1)(b) of the Indian Act, 1970, which provided that a woman who marries a Non-Indian is not entitled to be registered. The matter was referred to a county court Judge, sitting as persona designata under the Act, and he upheld the decision. The Federal Court of Appeal set his decision aside, but on further appeal by the Attorney General to the Supreme Court of Canada, the Court restored the decision earlier reached by the county court Judge, which favored the interests of the Indian community and allowed the appeal.

In the second appeal, Isaac v. Bedard, Respondent, B, was also an Indian woman who had married and separated from her Non-Indian husband. ${ }^{44}$ She lived off the reserve during the subsistence of the marriage. When they separated she returned to the reserve to live in the house bequeathed to her in terms of her mother's will. The Appellants, members of the Six Nations Council, requested the District Supervisor to serve a notice to quit on the respondent. She was also served a resolution ordering her to dispose of property she held. The Supreme Court of Ontario found in favor of the respondent by declaring Section 12(1)(b) of the Indian Act inoperative, and the notice to quit, along the resolution, of no effect.

On a direct appeal to the Supreme Court of Canada by the Six Nations Council, the Court found the section operative and allowed the appeal by a majority of three to one. The court held that the Canadian Bill of Rights could not render the impugned provisions inoperative because Section. 91(24) of the British North America Act of 1867 vested exclusive legislative authority in Parliament to legislate in relation to Indians and lands reserved for Indians. This power could not be exercised without enacting laws establishing qualifications required to entitle persons to enjoy Indian status and the rights and privileges of Indians under the Act. "The conditions imposed by Parliament for the use and occupation of Crown Lands reserved for Indians are a necessary part of the structure created by Parliament for the internal administration of the life of Indians on reserves and their entitlement to the use and benefit of Crown land situate thereon." 45 They were imposed in the discharge by Parliament of its constitutional function under the said provision and a change in those conditions must be effected for that purpose. "Parliament, in statutorily proclaiming certain fundamental rights in general terms in the Canadian Bill of Rights, cannot have intended to override the provisions of the Indian Act." 46

The provision in Section 12(1)(b) was challenged on the ground that it infringed the Respondents' rights to equality before the law. The court held, however, that equality before the law is not effective to invoke the egalitarian concept, as enshrined in the 14 Amendment of the US Constitution. ${ }^{47}$ The

44. Isaac v. Bedard, (1973) D.L.R. 481.

45. Id. at 481-82.

46. Id. at 482 .

47. Id. 
court stated that it must be read in its context as a part of the rule of law and means equality in the administration or application of the law by the authorities charged with enforcement of the law. Further, no inequality in the administration and enforcement of the law, as between Indian men and women, flows as a necessary result of the application of Section 12(1)(b) of the Indian Act. On equality before the law, Judge Ritchiesaid:

[T]he question to be determined in these appeals is confined to deciding whether the Parliament of Canada in defining the prerequisites of Indian status so as not to include women of Indian birth who have chosen to marry non-Indians, enacted a law which cannot be sensibly construed and applied without abrogating, abridging or infringing the rights of such women to equality before the law. ${ }^{48}$

He added:

Equality before the law . . . carries the meaning of equal subjection of all classes to the ordinary law of the land as administered by the ordinary Courts, and in my opinion the phrase "equality before the law" as employed in Section 1(b) of the Bill of Rights is to be treated as meaning equality in the administration or application of the law by the law enforcement authorities and the ordinary Courts of the land. ${ }^{49}$

The second case, Santa Clara Pueblo v. Martinez, ${ }^{50}$ was decided in the United States. In that case, Respondents, a female member of the Santa Clara Pueblo tribe and her daughter, brought an action for declaratory and injunctive relief against petitioners, the Pueblo and its Governor, alleging that a Pueblo ordinance that denied tribal membership to the children of female members who marry outside the tribe, but not similarly situated children of men of that tribe, violated Title I of the Indian Civil Rights Act of 1968. Title I provides that "no Indian Tribe in exercising powers of self-government shall deny to any person within its jurisdiction the equal protection of its laws." 51

Indeed, the court noted the central purpose of the Indian Civil Rights Act, which was, "to secure for the American Indian the broad constitutional rights afforded to other Americans and thereby to protect individual Indians from arbitrary and unjust actions of tribal governments." 52 However, it was observed that Indian tribes have long been recognized as immune at common law from

49. Id. at 495 .

50. 436 U.S. 49 (1978).

51. Id. at 51; see also Indian Civil Rights Act, 25 U.S.C.S. §§ 1301-1303 (1968).

52. Martinez, 436 U.S. at 61. 
suit, traditionally enjoyed by sovereign powers. Also, tribal sovereignty is subject to the superior and plenary control of Congress. Thus, without express congressional authorization to the contrary, the Indian tribes are exempt from suit. Therefore, if Congress wished to waive this immunity, it would do so expressly by legislation rather than by implication. The court held that the Respondents' suit against Pueblo was accordingly barred by its sovereign immunity. ${ }^{53}$

Title I of the Indian Civil Rights Act of $1968,{ }^{54}$ does not authorize the bringing of civil actions for declaratory or injunctive relief, nor can such authority be implied. The remedy of an injunctive and declaratory relief is of a civil nature. For that reason, it was not available to the Respondents. The court found that the only remedial provision, which Congress supplied in Title $I$, is the privilege of the writ of habeas corpus. This remedy is made available "to any person, in a court of the United States, to test the legality of his detention by order of an Indian tribe." in the Title. It is clear that the privilege can be exercised only in the criminal law context.

Bearing in mind the legislative purpose of protecting tribal sovereignty, Congress settled on habeas corpus as the exclusive means for federal-court review of tribal proceedings and chose a less intrusive review mechanism. ${ }^{56}$ This was based on its legislative investigation into tribal compliance with constitutional norms in both civil and criminal contexts, which revealed that most serious abuses of tribal power occurred in the administration of criminal justice. $^{57}$ Justice Marshall found that, "[i]n light of this finding, and given Congress' desire not to intrude needlessly on tribal self-government, it is not surprising that Congress chose at this stage to provide for federal review only in habeas corpus proceedings." 58 Accordingly, the majority of the Court (per Justice Marshall) held that Section 1302 did not impliedly authorize actions for declaratory or injunctive relief against either the tribe or its officers.

In arriving at its decision, the court rejected proposals for federal review of alleged violations of the Act arising in a civil context, ${ }^{59}$ noting that since Congress did not expose tribal officials to the full array of federal remedies, as are federal and state officials, it may also be considered that "resolution of statutory issues under Section 1302 and particularly those issues likely to arise in a civil context, will frequently depend on questions of tribal tradition and custom which tribal forums may be in a better position to evaluate than federal courts." 60

53. Id. at 58 .

54. 25 U.S.C. $\S \S 1301-1303$.

55. Martinez, 436 U.S. at 58 (quoting 25 U.S.C. $\$ 1303$ ).

56. Id. at 67.

57. Id. at 71 .

58. Id.

59. Id. at 72 .

60. Id. at 71 
These two cases no doubt demonstrate global concern for the protection of culture and traditional institutions. The effect of the decisions in these cases is that discrimination between men and women in a culture is not new and is not necessarily inequitable. It should also be added that the Governments of both countries are mindful of the need for the preservation of culture and made such provisions, which enabled the courts to decide as they did.

The need for the preservation of culture was also stressed in the African Banjul Charter on Human and Peoples' Rights. ${ }^{61}$ In Attorney-General v. Dow, ${ }^{62}$ the Court of Appeal in Botswana had to interpret the provisions of the Botswana Citizenship Act, ${ }^{63}$ which provided that "a person born in Botswana shall be a citizen of Botswana by birth and descent if, at the time of his birth: (a) his father was a citizen of Botswana; or (b) in the case of a person born out of wedlock, his mother was a citizen of Botswana." 64 The claim of the Respondent was that the Act breached her fundamental rights because it specifically made a discriminatory provision in that, while a male Botswana citizen could pass citizenship to his children born out of wedlock, she could not do so by virtue of being a woman. ${ }^{65}$ The issue was whether Section 15 of the Botswana Constitution, ${ }^{66}$ which forbids any law that is discriminatory on grounds of race, place of origin, political opinions, color, creed, or sex, precluded the enactment of legislation containing provisions that are prima facie discriminatory against women, such as in the Citizenship Act. Judge Aguda referred to Articles 2, 3, and 18(3) of the African Charter on Human and Peoples' Rights, and reached the conclusion that the charter expects all persons to be treated equally, without discrimination on ground of sex, and that since Botswana is a party to the Charter, it cannot allow its national legislation to make provisions that will be in conflict with her international undertaking.

It is submitted that Aguda. was wrong in not reading the African Charter as a whole, as he was urged when interpreting the Constitution. The learned judge had said while interpreting the Botswana Constitution that, "[i]t will be doing violence to the Constitution to take a particular provision and interpret it [one way]." ${ }^{\circ 7}$ If he had done the same with reference to the African Charter and had brought into view all relevant provisions of the Charter for consideration, he would have discovered that the Charter expects the court to

61. OAU Document, 21 I.L.M. 58 (1982). This was adopted by the 18th Assembly of the Heads of State and Government of the Organization of African Unity (OAU), now African Union (AU) on June 27, 1981 at Nairobi, Kenya; it entered into force on October 21, 1986. Id.

62. (1991) L.R.C. (Const.) 574 (Bots.).

63. Botswana Citizenship Act 25 of 1982 (amended by Act. 17 of 1984).

64. Id.

65. See Dow, (1991) L.R.C. (Cons.) 574 (Bots.). In terms of the law in force prior to the Citizenship Act, the child born before the marriage was a Botswana citizen, whereas in terms of the Act, the children born during the marriage were not citizens of Botswana, and therefore were aliens in the land of their birth.

66. BoTs. CONST. ch. II, $\S 15$ (amended 1987).

67. Dow, (1991) L.R.C. (Const.) at 688. 
take cognizance of the values and traditions of the African people in reaching its decision. With specific reference to Article 18(3), Aguda said:

One may be permitted once more to note the African Charter on Human and Peoples' Rights Article 18(3). It says emphatically that 'The State shall ensure the elimination of every discrimination against women and also ensure the protection of the rights of the women and the child as stipulated in international declarations and conventions'. In my view there is clear obligation on this country like on all other African states signatories to the Charter to ensure the elimination of every discrimination against their women folk. ${ }^{68}$

But other provisions, which ought to have been considered, are Preamble 4, Articles 17(3), 18(1), 18(2), and 29(1). Preamble 4 of the Charter requires State Parties to the Charter to take into consideration the virtues of their historical tradition and the values of African civilization, which will inspire and characterize their reflection on the concept of human and people's rights. Article 17(3) provides that the promotion and protection of moral and traditional values recognized by the community shall be the duty of the state. Article 18(3) relied upon by the learned judge, is preceded by paragraphs 1 and 2. Paragraph 1 provides that the family shall be the natural unit and basis of society; it shall be protected by the state, which shall take care of its physical health and morals. Paragraph 2 provides that the state shall have the duty to assist the family, which is the custodian of morals and traditional values recognized by the community. Lastly, Article 29(1) enjoins the individual to preserve the harmonious development of the family and to work for the cohesion and respect of the family, to respect his parents at all times and to maintain them in case of need.

These provisions point to the fact that the Charter was concerned about the preservation of African culture and values including the centrality of family in African traditions. Any provision in the Charter that may appear to negate or contradict this concern must be read subject thereto. It is most unfortunate that Judge Aguda did nothing of the sort and took Articles 2, 3, and 18(3) as if they were the only Articles in the Charter. It is submitted that in the special circumstance of African culture, which is informed by the need to ensure the sustenance of the family and its property, the African Charter contains enough provisions to call for care. Judge Muchechetere said in Magaya:

In my view, all the courts can do is to uphold the actual and true intention and purport of African Customary law of succession against abuse, as was done in the Masango case. ... "The obligation to care for family members, which 
lies at the heart of the African social system, is a vital and fundamental value, which Africa's Charter on Human and Peoples' Rights is careful to stress." Paragraph 4 of the Preamble to the Charter urges parties to pay heed to "the virtues of the African historical tradition and the values of African civilization" and Chapter 2 provides an inventory of the duties that individuals owe their families and society. Article 29(1), in particular, states that each person is obliged to preserve the harmonious development of the family and to work for the cohesion and respect of the family; to respect his parents at all times, to maintain them in case of need. ${ }^{69}$

These are vital injunctions in the reading of the Charter, and indeed in interpreting any of its provisions. Aguda fell into error when he did not inquire into the rationale behind the African custom before criticizing it. He showed his distaste for the custom, which he thought discriminated against women, by stating:

In considering whether this court can interpret [S]ection 15 of the Constitution in such a way as to authorize legislation, which in its term and intent is meant to discriminate on ground of sex, in this case the female sex, it appears to me that, now more than ever before, the whole world has realized that discrimination on ground of sex, like that institution which was in times gone by permissible both by most religions and the conscience of men of those times, namely, slavery, can no longer be permitted or even tolerated, more so by the law. ${ }^{70}$

Judge Purckrin, sitting in the same court, disagreed. He said:

I do not perceive that it is my duty as a Judge of this court to impose my personal convictions upon an interpretation of the Constitution, for to do so would, in my respectful view, permit this court to become the overlord of the constitution rather than its guardian. ${ }^{71}$

He added:

I am of the view that the Constitution, and particularly Section 15 , thereof, does not preclude the legislature from enacting a

69. Magaya, 1999 (1) ZLR 100, 113-14 (S) (citing Masango, S 66-86 and quoting BENNETT, Supra note 3, at 6.

70. Dow, (1991) L.R.C (Cons.) 574 (Bots.).

71. Id. 
statute which provides that citizenship shall pass in a patrilineal but not matrilineal fashion. In my view the provisions of Section 15 of the Constitution are clear and it is not necessary to invoke such extraneous aids to interpretation as Botswana's international obligations under various conventions and the like. ${ }^{72}$

\section{ILLEGITIMACY}

African society does not recognize the concept of illegitimacy as it is used in the Western world. ${ }^{73}$ Many writers on African customary law accept this view. ${ }^{74}$ Bennett writes: "Illegitimacy is said to have no place in customary law since 'birth in or out of wedlock is irrelevant to the child's status in the community or its legal rights and duties.' The legal disadvantages of illegitimacy are indeed not as great in customary law as they used to be in western legal systems." 75 However, it may not be correct to say that the concept of illegitimacy is unknown to customary law. Coker argues:

It is generally supposed that there is no status of illegitimacy in native law and custom: this, however, is not correct, for there is a status of illegitimacy as opposed to that of legitimacy. The latter entitles the subject ipso facto to succeed to property; the former disentitles the subject from so succeeding, unless his rights are "legalised by an acknowledgment of paternity" by the father. ${ }^{76}$

Illegitimacy is the result of lack of marriage between biological parents; therefore, any discussion about illegitimacy must involve an inquiry into the relationship of these parties.

Inheritance, in general, is reserved for children born of a valid marriage. However, customary law appears to be flexible on this issue, leaning against illegitimacy at every opportunity. In the past, illegitimate children were most unfavored by society, which regarded them as issues of immorality, filius nullius. When an attempt was made to change their status, majority opinion, especially in England, did not like equating the legal position of illegitimate

72. Id.

73. See generally E. Schoeman, Choice of Law and Legitimacy: Back to 1917?, $116 \mathrm{~S}$. AFR. L.J. 288, 292 (1999) (discussing the "lawful wedlock theory" and legitimacy).

74. See S. M. Seymour, Proof of Legitimacy or Illegitimacy, in BANTU LAW IN SOUTH AFRICA 226 (3d. ed. 1970); T. W. BENNETT, A SOURCE BOOK OF AFRICAN CUSTOMARY LAW FOR SOUTHERN AFRICA 358 (1991); S. Burman, Illegitimacy and the African Family in a Changing South Africa, in ACTA JURIDICA 36 (T.W. Bennett et al. eds., 1991).

75. See BENNETT, supra note 74 , at 358.

76. G. B. A. COKER, FAMILY PROPERTY AMONG THE YORUBAs 266(African Universities Press, Lagos, 3rd ed. 1966). 
children with that of legitimate ones for fear that such a step might weaken respect for marriage and the family. ${ }^{77}$

In African custom, absence of marriage does not preclude a father from having access to his children. Whether a father plays a role as a custodial parent, or just as guardian, depends on whether he abides by certain customary rules. Even where there is no marriage, the father of a child can have custodial rights to the child. For example, in some parts of Southern Africa when the natural father pays isondlo $^{78}$ he obtains custody and guardianship of the child. ${ }^{79}$ The courts originally refused to apply this rule because it was regarded as child-trafficking, and against public policy. ${ }^{80}$ In other parts of Africa, acknowledgement of paternity is sufficient to transfer a child into the father's family, just, as isondlo achieves the same result. In this regard, it is not a requirement that the father must be married to the mother of the child.

In Subuola Alake v. Bisi Pratt, ${ }^{81}$ the West African Court of Appeal held that "the evidence in this case is that under Yoruba law and custom all legitimate children are entitled to share in their father's estate, and the Appellants having been held to be legitimate, the question of their parents' marriage is not a relevant subject for investigation." 82 Likewise, in Savage $v$. Macfoy, ${ }^{83}$ Justice Osborne, expressed the following view:

The principle governing intestate succession among the Yoruba is that all children whether legitimate or not will inherit from their intestate deceased father. The only proviso is that the father of an illegitimate child must acknowledge paternity of his illegitimate child. In this respect there appears to be no difference between children born in native wedlock and the offspring of fortuitous connection, provided paternity has been acknowledged. ${ }^{84}$

Illegitimacy ceases to be relevant once children belonging to a deceased person are, or have been shown to be, his or there has been evidence of his acknowledgment of the children. The child becomes legitimate at the point of acknowledgment of his or her paternity, which may be at birth. A child who has been so acknowledged cannot be described as illegitimate. If his or her

77. A. H. MANChester, A MODERn Legal History OF ENGLAND AND WALES 1750-1950, 395 (Butterworths, London, 1980).

78. The transfer of a beast intended to compensate the family that brought up the child for the expenses incurred by the woman's family.

79. See The Law of South Africa: Indigenous Law 32 para. 146 (on file with author).

80. Mpawa v. Labano, 1938 NAC 121 (S).

81. 15 W.A.C.A. 20; see also In re. Herbert Macauley, 13 W.A.C.A. 304 (1951).

82. Alake 15 W.A.C.A. at 20-21.

83. (1909) R.G.C.R. 504.

84. Id. at 508. 
natural parents decide to marry, the child is not 'legitimated' for the purposes of customary law.

Returning to the decision of the South African Court of Appeal in $M$ thembu, ${ }^{85}$ which dealt with the issue of illegitimacy, there the court held that Tembi was an illegitimate child because there was no customary marriage between her mother and the deceased. The facts of this case have been stated under the primogeniture rule. The issue of marriage came before Judge Mynhardt, of the High Court. No evidence was offered on this issue. Counsel agreed that the matter should be decided on the basis that there had been no customary marriage. The learned judge, therefore, reached the conclusion that there was no customary marriage between the parties. He said:

Both the applicant and the first respondent decided not to adduce any evidence. The application must accordingly be determined on the basis that the applicant and the deceased were not married to each other and that Tembi was born out of wedlock. $^{86}$

Later he said:

In the present case the applicant was not married to the deceased. Her child, Tembi, is therefore an illegitimate child vis-a-vis the deceased and his family. Tembi has no right to inherit from the deceased. That is so simply because she is not the legitimate child of the deceased. It matters not that Tembi is a girl. Even an illegitimate son would have had no right to inherit intestate from the deceased. The disqualification of Tembi ... flows, therefore, from her status as illegitimate child and not from the fact that she is a girl and that the system of primogeniture is applied in customary law. In my view there cannot therefore be any talk of unfair discrimination on the grounds of sex or gender in the present case. It also follows that the value of equality has not been infringed. Moreover, Tembi has not been deprived of her right to support from her guardian. She had that right since birth and she is still entitled to be maintained and supported by her guardian. ${ }^{87}$

What the learned judge is saying here is that since he proceeded on the basis that Tembi is illegitimate because of absence of marriage between her parents, there can be no talk of unfair discrimination on the ground of sex or gender. Mpati, of the Supreme Court of Appeal, agreed with him and said:

85. 2000 (3) SA 867 (CC).

86. Mthembu v. Letscla, 1998 (2) SA 675, 679 (T).

87. Id. at 686 . 
As the court a quo held, Tembi, of course, is excluded from inheriting because she is illegitimate. The question of gender discrimination is not reached in this case and it is not desirable to address a question of such constitutional importance in a case in which it is academic. She would be in the same position as, for example, illegitimate male children. ${ }^{88}$

Counsel for the Appellant argued at the court, that the deceased child had been legitimized since the bridewealth had been paid in part. Mpati replied:

In casu, it is common cause that no customary union existed between the appellant and the deceased when Tembi was born. It is also common cause that no customary union was entered into subsequent to her birth. It follows that although part of the bridewealth was paid, without a customary union between her parents, Tembi was not legitimised. Mynhardt J was accordingly correct in holding that Tembi is illegitimate. ${ }^{89}$

It is unfortunate that evidence was not offered at the trial on the issue of marriage and that the case was determined on the basis that Appellant and the deceased were not married to each other. When the issue of marriage was argued at the Supreme Court of Appeal, the Court decided that there was no marriage between the deceased and Tembi's mother, because for there to be a customary marriage there must be payment of bridewealth and marriage. Counsel for the Appellant sought support for his argument that bridewealth was sufficient to constitute marriage. He quoted Burman as saying:

In customary law a child born within a customary union is presumed to be legitimate and thus part of its father's family. However, as outlined above, the crucial element in the marriage which transfers the child into the father's family is not the ceremony, as in civil law, but the payment of bridewealth, at least in part. ${ }^{90}$

Mpati said that counsel misread this passage and that the author "speaks of the crucial 'element in the marriage' which transfers the child into the father's family as being payment of bridewealth or part of it." 91 There must, he said, be a marriage distinct from payment of bridewealth. It is submitted that the court,

88. Mthembu, 2000 (3) SA at 882.

89. Id. at 879.

90. Id. at 878 (quoting Burman, supra note 74 ).

91. Id. 
insisting that customary law requires both payment of bridewealth and marriage, as two separate requirements, begs the question. Burman could not be understood as saying that this is the rule, as she said elsewhere:

A customary-law union, in practice if not as clearly in the text books, is a process rather than an event. By paying bridewealth (termed lobola among the Xhosa) to a woman's natal family, a man obtains rights over her and her offspring, and undertakes certain corresponding duties. In this way the woman and children are incorporated into his patriline and the wife's guardian forfeits his claims to them, though he retains residual rights of guardianship for the rest of her life. But payment of bridewealth may take many years or, indeed, may never be completed. While the maternal family may invoke their right to the children until such time as bridewealth is paid, they are very unlikely to do so as long as there remains the expectation - or hope - that the father will yet honour the bridewealth agreement. ${ }^{92}$

Mbatha also notes that, "[t]he conceptual separation of these two processes is misleading since they often take place at the same time. ${ }^{.93}$ Mpati referred to a statement in Warner" in support of his view. The learned author said that "in customary law[,] payment of bridewealth and marriage were required to legitimate children."

This statement is incorrect. In Mabena v.Letsoalo, ${ }^{96}$ the court defined a customary marriage as comprising two distinct legal actions: (i) the marriage agreement, which traditionally required the consent of the bride, the bridegroom, and the guardian of the bride, and (ii) the lobolo agreement, which traditionally required the consent of the guardian of the bride and the guardian of the bridegroom. ${ }^{97}$ The court did not define a customary marriage as requiring (i) marriage and (ii) payment of lobola as two different things. In that case, the only action that was established was payment of lobola to the bride's mother, and it was also shown that the payment was made by friends of the deceased. Yet the court concluded that there was a valid marriage in accordance with customary law. ${ }^{98}$

92. Burman, supra note 74 , at 38 .

93. Likhapha Mbatha, Reforming the Customary Law of Succession, 18 S. AFR. J. HuM. RTS. 259, 276 (2002).

94. H. Warner, Digest of South African Native Civil CaSe LaW $\S \S 1894-1957$ (1961).

95. Id. at 47-50 (Custom in Transkeian Territories and other areas, Claim by Natural Father of a Child: Pondo Custom).

96. Mabena v. Letsoalo, 1998 (2) SA 1068 (T).

97. Id. at 1073.

98. Id. at 1075 . 
In Bhe, discussed above, there was a dispute as to the payment of lobola. While the Applicant claimed that no lobola was paid, the Respondent said that it was paid. The Court resolved the issue in favor of the second Respondent, and held that the first and second Applicants were legitimate. ${ }^{99}$ Judge Ngwenya said that it has never been a requirement under customary law to pay lobola before a marriage is consummated. All that is needed is agreement for lobola. It may be deferred so long as circumstances do not permit payment. ${ }^{100}$

The South African Recognition of Customary Marriages Act of $1998^{101}$ appears now to have resolved the problem, if any existed before, since it provides in Section 3(1) as follows:

For a customary marriage entered into after commencement of this Act to be valid,

(a) The prospective spouses-

(i) Must both be above the age of 18 years; and

(ii) Must both consent to be married to each other under customary law; and

(b) The marriage must be negotiated and entered into or celebrated in accordance with customary law.

Apart from the minimum age of eighteen years and the consent of the parties, the only other requirement in this subsection is that the marriage must be negotiated and entered into or celebrated in accordance with customary law. The Act does not require both to take place before customary marriage can be valid. The words used by the Act are "negotiated" and "entered into" or "celebrated." These words are used as disjunctive and not conjunctive, requiring either one or the other, but not both.

Although lobola is not made a requirement of customary marriage by this Act, it was featured in Section four, which deals with registration of customary marriages. This Subsection included lobola as one of the particulars that a registering officer must record when registering a marriage. This does not make the payment of lobola a requirement of a valid customary marriage for the purposes of the Act. Reference to lobola is also found in the definition section of the Act, as follows:

Lobolo means the property in cash or in kind, whether known as lobolo, bogadi, bohali, xuma, lumalo, thaka, ikhazi, magadi, emabheka, or by any other name, which a prospective

99. Nonkululeko Bhe v. Khayelisha, No. 9489/2002 (C.H.C. Sept. 25, 2003) (unreported judgment of the Cape High Court delivered by Ngwenya, J.) (on file with author).

100. Id.

101. $\S 1$ of Recognition of Customary Marriages Act 120 of 1998 (S. Afr.). 
husband or the head of his family undertakes to give to the head of the prospective wife's family in consideration of a customary marriage. $^{102}$

The conclusion may be reached that, even though lobola is not made a requirement of a valid customary marriage, the practice is recognized by the Act, and indeed the payment of it, either in whole or in part, is the best evidence that a marriage was negotiated and entered into in accordance with customary law within the meaning of this Act.

Before leaving this issue, the constitutionality of the concept of illegitimacy must be considered. In South Africa, Sections 9(3) and (4) of the 1996 Constitution prohibit discrimination on ground of birth. ${ }^{103}$ The 1993 Constitution, Section 8(2) did not refer to birth, although it included social origin as a ground for which discrimination is prohibited. ${ }^{104}$ Some writers have argued that prohibition of discrimination on ground of social origin included birth, and this meant that illegitimacy was caught by the provision in Section $8(2){ }^{105}$ They concluded that discrimination against illegitimate children was prohibited by this provision. The 1996 Constitution, in addition to including social origin, now adds birth as one of the grounds upon which discrimination is prohibited. It is clear, therefore, that discrimination on the grounds of illegitimacy is caught by this provision.

Indeed, in 1997 the South African Constitutional Court, in Fraser $v$. Children's Court, ${ }^{106}$ held that an unmarried father of an illegitimate child may insist that his consent be obtained in the adoption of his child. The father of the illegitimate child had in this case challenged the provision of Section 18(4)(d) of the Child Care Act ${ }^{107}$ in so far as it dispenses with father's consent for the adoption of an illegitimate child. The main ground of attack was that the provision was inconsistent with Section 8 of the Interim Constitution, as it violated the right to equality and the right of every person not to be unfairly discriminated against. The court held that the provision impermissibly discriminated between married fathers and unmarried fathers. ${ }^{108}$ Parliament was directed to correct the defect by an appropriate statutory provision within a period of two years. It appears that there has since been compliance with this directive of the court.

102. Id.

103. S. AFr. CoNST. $\S \S 9(3)-9(4)$ (amended 1996).

104. Id. $\S 8(2)$.

105. Angelo Pantazis \& Tshepo Mosikatsana, Children's Rights, in ConstrTutional Law OF SOUTH AFrICA 33-1 (M. Chaskalson et al. eds., 1999) (referring to the tenth report of the Technical Committee on Fundamental Rights during Transition, where it is said that social origin was deemed to encompass birth, class, and status).

106. 1997 (2) BCLR 153 (CC).

107. $\S 18(4)$ (d) of Child Care Act of 1983 (S. Afr.).

108. Fraser, 1997 (2) BCLR at 153. 
The substituted Section 18(4)(d) of the Act now provides that in the case of a child born out of wedlock, the consent of both the mother and the natural father is required. ${ }^{109}$ Although this case does not deal directly with illegitimacy, the Constitutional Court may already be moving in this direction by striking out the provision in a statute that discriminates against an unmarried father of an illegitimate child. Further, in Bhe, the learned judge observed that whether the first and second Applicants are legitimate or not does not affect the consequences flowing from the status of the legal relationship between their parents at the time of their fathers' death. ${ }^{110}$ He said also that, in his view, even if the children were illegitimate, he would not refuse them the relief sought in the light of the constitutional era in which we live. ${ }^{111}$ This supports the earlier argument that the concept of illegitimacy is in conflict with the provisions of the South African Constitution against discrimination.

The Nigerian Constitution ${ }^{12}$ provides that "no citizen of Nigeria shall be subjected to any disability or deprivation merely by reason of the circumstances of his birth." Illegitimacy as a concept will also be affected by this provision in the Constitution. ${ }^{113}$ Chapter 3 of the Constitution of Zimbabwe ${ }^{114}$ does not contain a prohibition of discrimination on the ground of birth. Illegitimacy under customary law will therefore not be affected in that country. In Ghana, Section 17 of the Constitution, ${ }^{115}$ which prohibits discrimination, does not include birth. The same applies to the Constitution of Botswana, ${ }^{116}$ which does not include discrimination on grounds of birth. It is arguable that the Constitutions of Ghana and Botswana will affect the concept of illegitimacy in their countries, since they both include prohibition against discrimination on the grounds of social status.

\section{LATER DEVELOPMENTS}

The treatment of children equally, irrespective of their parents' marital status, is now popularized as human rights culture. Many countries the world over have been finding solutions to the plight of children who are being disinherited on the ground that they are illegitimate due to the absence of

109. See $\S 4$ of Adoption Matters Amendment Act 56 of 1998 (S. Afr.).

110. Nonkululeko Bhe v. Khayelisha, No. 9489/2002 (C.H.C. Sept. 25, 2003) (unreported judgment of the Cape High Court delivered by Ngwenya, J.) (on file with author).

111. Fraser, 1997 (2) BCLR at 153.

112. NIG. CONST. § 42 (2) (1999).

113. It was however held in Da Costa v. Fasehun, suit No. M/150/80 (unreported decision dated May 22, 1981, by the, High Court of Lagos, Nigeria) while interpreting Section 39(2) of the Nigerian Constitution of 1979 , that the provision will not confer a right of inheritance to children born out of wedlock on the ground that it will be contrary to public policy.

114. ZIMB. Const. amend. XVI, ch. 3 (2000).

115. GHANA CONST. $\S 17$ (1992) (Discrimination is prohibited on grounds of gender, race, color, political opinion, religion, creed or social, or economic status).

116. Bots. CONST. (1996) (Discrimination is prohibited on grounds of gender, race, color, political opinion, religion, creed, or social status.). 
marriage between their parents. For example, originally in England, in accordance with the general rule at common law, only legitimate persons and those claiming a relationship through legitimate persons could participate in intestate succession. In 1969 the Family Law Reform Act permitted illegitimate children and their parents to succeed each other. ${ }^{17}$ Now, its Family Law Reform Act of $1987^{118}$ provides that, for the purposes of the distribution of the estate of an intestate, any relationship shall be construed without regard to whether the parents of the deceased, the claimant or any person through whom the claimant is related to the deceased were married to each other.

New Zealand has also removed the distinction between legitimate and illegitimate issue. Section 3(1) of its Status of Children Act provides that "the relationship between every person and his father and mother shall be determined irrespective of whether the father and mother are or have been married to each other."119

Additionally, the International Covenant on Economic, Social and Cultural Rights requires equality of status for all children. It reads:

Special measures of protection and assistance should be taken on behalf of all children and young persons without any discrimination for reasons of parentage or other conditions. Children and young persons should be protected from economic and social exploitation. Their employment in work harmful to their morals or health or dangerous to life or likely to hamper their normal development should be punishable by law. States should also set age limits below which the paid employment of child labour [sic] should be prohibited and punishable by law. ${ }^{120}$

Bennett thinks that, "this implies abolition of the stigma of illegitimacy." It21 is doubtful whether this view is correct. It appears the Article referred to here contemplates a situation where the state takes measures to protect children. In doing so, the state should not discriminate on the basis of the parentage of such children, which could include illegitimacy. The provision cannot be said to prohibit illegitimacy.

The European Convention on the Legal Status of Children Born out of Wedlock provides that "a child born out of wedlock shall have the same right of succession in the estate of its father and its mother and of a member of its

117. See Family Law Reform Act, ch. 46, § 14 (1969) (Eng.).

118. Family Law Reform Act, ch. $42, \S 18$ (1987) (Eng.), reviewed by N. LowE \& G. Douglas, Family Law 879 (Butterworths, Dublin, 9th ed. 1998).

119. Status of Children Act, 1969 (N.Z.).

120. G.A. Res. 2200A, U.N. GAOR, 21 st Sess., Supp. No. 16, at 49, U.N. Doc. A/6316 (1966).

121. T. W. Bennett, Compatibility of African Customary Law and Human Rights, in ACTA JURIDICA 18, 27 (T. W. Bennett et al. eds., 1991). 
father's or mother's family, as if it had been born in wedlock."122 This Convention, rather than the one referred to earlier, is perhaps more relevant to the issue of elimination of the stigma of illegitimacy.

In Africa, post-colonial governments have paid close attention to customary law of succession. For example, Malawi's Wills and Inheritance Act, ${ }^{123}$ was enacted to reconcile the interests of customary law heirs with those of surviving spouses and children. In Ghana, the Intestate Succession Law was enacted in $1985,{ }^{124}$ which provides for the surviving spouses and children to inherit the house and household chattels. Zambia enacted the Intestate Succession Act of 1989 to achieve the same equitable distribution among the spouses and children of an intestate. In Zimbabwe, the Administration of Estates Amendment Act of 1997 was enacted to introduce a new code of intestate succession applicable to anyone subject to customary law at the time of his death. ${ }^{125}$

The situation in South Africa offers perhaps the biggest challenge. ${ }^{126}$ In this country, there have even been calls for harmonization of the common law and customary law systems. ${ }^{127}$ The law commission of the country has also suggested that "[i]nstead of attempting to reform customary law, the common law could be substituted." 128 It recommends ${ }^{129}$ that the Intestate Succession Act be made applicable to estates that are subject to customary law. ${ }^{130}$ South

122. European Convention on the Legal Status of Children Bom out of Wedlock, art. 9 (1975) (The convention was opened for signature on 15th September 1975 and for ratification on 11th August 1978. As of October 12, 2004 only twenty-one countries had signed and ratified it.).

123. Wills and Inheritance Act of 1967 , para. 25 (Malawi).

124. See G. R. Woodman, Ghana Reforms the Law of Intestate Succession, 29 J. AFR. L. 118 (1985) (discussing Ghana's Intestate Succession Law).

125. See generally South African Law Commission, supra note 38, at para. 4.4 (discussing Zimbabwe's Administration of Estates Act of 1997).

126. A draft bill on the Amendment of Customary Law of Succession was tabled before Parliament in 1998 but was withdrawn after objections to the bill were raised by interested parties. Now there is a new draft bill that is to be tabled in Parliament, which seeks to repeal the illegitimacy rule and the rule of primogeniture, the duty of an heir to support the family of the deceased person, and which makes provision for surviving spouses.

127. See I. Currie, Indigenous Law, in Constitutional LAw of South AFriCa 36 (M. Chaskalson et al. eds., 1999); M. Pieterse, supra note 2; J. D. Van Der Vyver, Human Rights Aspects of the Dual System Applying to Blacks in South Africa, 15 COMP. \& INT'L L.J. S. AFR. 306 (1982).

128. South African Law Comission, supra note 38, at para. 3.1.

129. Id. at para. 4.2. See generally South African Law Commission, Discussion Paper 82, Project 90, Harmonisation of the Common Law and the Indeginous Law (1999).

130. Section 1(2) of the Intestate Succession Act 81 of 1987 provides that "[n]otwithstanding any [1]aw or common law ... illegitimacy shall not affect the capacity of one blood relation to inherit the intestate estate of another blood relation." Id. $\S 1(2)$. Subsection (4)(b) expressly excludes estates that are subject to customary law, by providing that "[i]n the application of this section - 'intestate estate' includes any part of any estate which does not devolve by virtue of a will or in respect of which section 23 of the Black Administration Act, ... does not apply." Id. $\$ 1(4)(b)$. Section 23(1) and (2) provide that: "All movable property belonging to a Black and allotted by him or accruing under Black Law or Custom to any woman 
Africa, like many countries on the continent, has to contend with the clash between the common law and customary law.

The conflict that exists between these two systems has currently moved to the Constitution and customary law. ${ }^{131}$ The new call for harmonization must be seen in that light. The proponents of harmonization are no doubt aware that the Constitutions of many African countries are largely based on common law principles. They must also know that any harmonization process will result in customary law being absorbed into the common law. Caution is, therefore, called-for in dealing with this issue. Pieterse notes:

South African law has in the past been overwhelmingly Eurocentric. Cultural preferences of a small sector of the South African community have been forced onto the majority of the population. The Constitutional commitments to nonracialism, respect of cultural diversity and equality before the law thus require that African cultural values are no longer treated as "inferior". For South African Law truly to be legitimate, it must reflect the cultural perceptions of the majority of its citizens. There is further no reason why cultural interests should be restricted to the realm of customary law and not also infiltrate other areas of South African law. ${ }^{132}$

A harmonized legal system must first meet the precondition of harmonizing relations among people across races and cultures. Realistically, this still remains a dream in many countries in Africa. The problem with the concept of a single legal system is that it assumes that such a system is what people need. On the contrary, what is needed is recognition that African customs exist, that the majority of African people still live by them, and that they must therefore be protected. The South African Law Commission made the same point with regard to the call for harmonization of the law of succession in South Africa. It said:

While this solution would have the advantage of providing a single law of succession for the whole country, it should not be adopted without careful consideration, for different cultural groups may be unwilling to surrender their legal heritages. Maintaining a policy of dualism accepts the fact of South

with whom he lived in a customary union, or to any house, shall upon his death devolve and be administered under Black Law and Custom." All land in Tribal settlement held in individual tenure upon quitrent conditions by a Black shall devolve, upon his death, upon one male person, to be determined in accordance with tables of succession to be prescribed under subsection (10). Id. $\S 23(1)(2)$.

131. For a more detailed discussion on this issue, see $\mathrm{C}$. Himonga and $\mathrm{C}$. Bosch, The Application of African Customary Law Under the Constitution of South Africa: Problems Solved or Just Beginning?, S. AFR. L.J. 117, 364 (2000).

132. Pieterse, supra note 2 , at 390-91. 
Africa's legal and cultural diversity, a reality that the Constitution demands we respect. ${ }^{133}$

Kerr also writes:

Change is needed; but, especially in a democracy, those affected by customary law need to have an opportunity to state their views with the assurance that 85 percent of their system of law will not need to come from other sources. This is not to say that the values in the Bill of Rights are to be disregarded. If those affected by customary law are persuaded to adopt new values, such of those values as the legislature(s) adopt and enact are incorporated into customary law. ${ }^{134}$

\section{CONCLUSION}

The question of the compatibility of the primogeniture rule with the Constitutions of African countries will continue to be the subject of debate. As shown, in some cases the Constitutions exclude customary law from their application. In others, there is no such exception, but the Constitutions provide for the recognition of culture. What then is the future of African culture in an era of constitutional provisions for equality and non-discrimination? The answer lies in calling for a more conscious effort on the part of African Governments to ensure the preservation of African culture by avoiding constitutional provisions that will override it. The African Charter on Human and Peoples' Rights should be reviewed in the light of the decision in AttorneyGeneral v. Dow. Its provisions should expressly be made subject to the preservation of African culture and values in line with Preamble 4. The review must include Articles 60 and 61 of the Charter, that is, those Articles relating to applicable principles. These Articles appear to suggest that African practices are matters for subsidiary measures and should only be considered when they are not inconsistent with international norms of human and peoples' rights.

When Africans take a keen interest in the cultures of the continent, they earn the stigma of being romanticists, who desire to live in the past. Yet, Western cultures decimate African cultures, destroy the African moral fiber and lead to atrophy of the social fabric of African societies. ${ }^{135}$ The old order treated African customs with contempt. The new order recognizes them only insofar as they conform to democratic values. It treats African customs with caution and

133. See South African Law Commission; supra note 38, at para. 3.1.

134. A. J. Kerr, Inheritance in Customary Law Under the Interim Constitution and Under the Present Constitution, 115 S. AFR. L.J. 262, 269 (1998).

135. See Medium-Term Strategy, supra note 1 (stating the UNESCO medium term strategy for the Africa region quoted at the beginning of this article). 
the result is that they are vulnerable. When African customary law receives mention, it is less than what it deserves. The only bridge that exists between the new and the old is that both have failed to give African customary law full recognition and protection. The old order made assumptions about what is wrong and right for African people. The new order continues to make those assumptions on the pretext that it is the people themselves who have made the choice through their Constitutions.

This century is regarded as the century of Africa in which she must come into her own, shed the shackles of dependence, and put herself on the path of self-expression. The African Millennium under the African Union must not be in name only. The vision that the expression encapsulates has to be concretized. In this millennium, African Union must strive to unite Africans across the continent around the same values and ideals, instill in them pride for their cultures, traditions, and beliefs. There must be continuous learning about African culture, beyond treating it as purely tourism, an exotic delicacy exclusively reserved for consumption by tourists. 
